\title{
Identification of clinical isolates of Neisseria gonorrhoeae by a coagglutination test
}

\author{
M. BARNHAM AND A. A. GLYNN \\ From the Department of Bacteriology, Wright-Fleming Institute, St. Mary's Hospital Medical School, \\ London W2 1PG, UK
}

SUMMARY Ninety-eight per cent of laboratory isolates of Neisseria gonorrhoeae from a veneral disease clinic gave positive reactions with a gonococcal coagglutination test. The prototype reagent, however, was poor at distinguishing between different species of the genus Neisseria: $75 \%$ of strains of Neisseria meningitidis and $40 \%$ of other Neisseria species tested gave positive reactions. None of the organisms other than Neisseria growing on the diagnostic cultures from the clinic gave positive reactions. We therefore suggest that the present reagent is unsuitable for testing isolates from the upper respiratory tract. The technique is simple, rapid, and convenient and with a more specific antibody could be useful. Results of coagglutination reactions of 126 strains of Neisseria grown on serum-containing and serum-free media were very similar and there is no need to use special serumfree media.

Laboratory diagnosis of gonorrhoea is based mainly on isolation of the organism. Features commonly used for identifying isolates include the ability to grow on selective culture media, colonial appearance, the Gram reaction and bacterial morphology, oxidase and sugar fermentation reactions, and immunofluorescent staining. Laboratories vary in their choice of tests-simple and quick techniques are generally preferred.

The gonococcal coagglutination test is a rapid slide agglutination test in which rabbit antigonococcal antibodies, bound by their Fc portions to protein A-bearing staphylococci, react with gonococci to produce heavy, easily visible agglutination. This reaction is compared with a control in which the staphylococci bear no specific antibody. The test was developed for the identification of $N$. gonorrhoeae by Danielsson and Kronvall (1974). Their results with coagglutination agreed well with those of standard fermentation and immunofluorescence tests, but they emphasised that to eliminate cross reaction with $N$. meningitidis and some strains of Moraxella, Haemophilus, and Pseudomonas, it was essential to absorb the antiserum used with meningococci and Moraxella.

The principle of the coagglutination test has been applied to the serological investigation of other

Received for publication 1 August 1977 organisms, including the typing of pneumococci (Kronvall, 1973) and Mycobacteria (Juhlin and Winblad, 1973) and the grouping of beta-haemolytic streptococci (Christensen et al., 1973; Edwards and Larson, 1974; Arvilommi, 1976; Hahn and Nyberg, 1976; Maxted et al., 1976).

We have examined strains of $N$. gonorrhoeae and other Neisseria and also some organisms of other genera and have compared the results with the conventional tests used in our laboratory.

\section{Material and methods}

\section{COAGGLUTINATION TEST}

The reagents used were those of a prototype gonococcus coagglutination test (Pharmacia Diagnostics AB) in which lyophilised test and control reagents are washed and suspended in phosphate buffer solution ( $\mathrm{pH} \mathrm{7.4)}$ and stored ready for use in dropper bottles. The antiserum used for the preparation of the test reagent had been absorbed with Moraxella and meningococcal organisms (Danielsson and Kronvall, 1974).

Colonies of organisms to be tested were sampled from the culture plate with a platinum loop and two smears were prepared on a clean, dry glass slide. The smears were allowed to dry for 30 seconds and then a drop of test reagent was added to one smear and of control reagent to the other. The drops were mixed 
thoroughly into the smears with the loop, starting with the control to ensure that no contamination with the sensitised test reagent could occur. The slide was then rocked slowly and observed for coagglutination with oblique transillumination and a dark background. Reactions were usually complete within a minute but if no reaction had occurred slides were re-examined after 2-3 minutes.

The Figure shows typical coagglutination test results with strains of $N$. gonorrhoeae. There is a marked coagglutination lattice in the reagent pool (left) while the control pool (right) shows suspended bacteria and a few clumps but no coagglutination. Occasional strains were encountered that were autoagglutinating, giving apparently similar reactions in both test and control pools. These strains were unreadable with the test. In the first part of the study the control reagent contained no immunoglobulin and false reactions were common. To overcome this an improved control reagent was obtained in which the staphylococci were coated with normal rabbit immunoglobulin. This reagent was used for the later experiments.

The method of scoring reactions finally adopted is shown in Table 1.

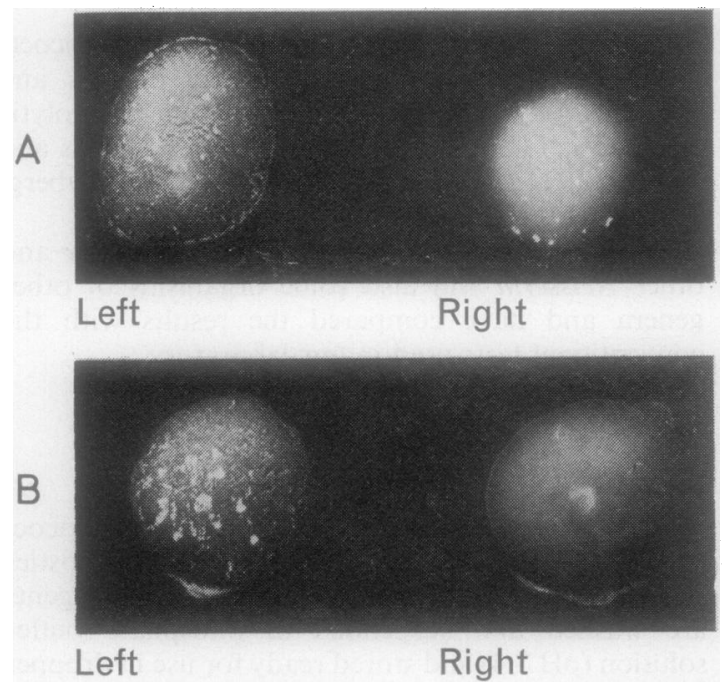

Figure Typical coagglutination test results with strains of $\mathrm{N}$. gonorrhoeae. Test reagent left, control reagent right.

(A) reaction.$+(B)$ reaction +++ .

\section{Results}

In a preliminary demonstration experiment 11 diagnostic laboratory technicians and doctors examined 12 strains of $N$. gonorrhoeae freshly isolated from clinical sources. Coagglutination tests were performed by one of us and the slides were kept in damp chambers to prevent evaporation while each was examined by the observers, who did not know the identities of the strains or which was the test and which the control slide.

Table 1 Scoring of agglutination. N. gonorrhoeae was diagnosed only if a strain had a score of + or more together with a negative control

\begin{tabular}{ll}
\hline Score & Appearance \\
\hline+++ & $\begin{array}{l}\text { Large, irregular clumps partly fused into a } \\
\text { coarse lattice } \\
\text { Mixed small and large granules, early lattice } \\
\text { formation }\end{array}$ \\
++ & Fine granules, definitely more than control \\
+ & Fine granules, little difference from control \\
\pm & No visible granules \\
\hline
\end{tabular}

The mean coagglutination score with the test $\frac{T}{8}$ reagent was $2 \cdot 3$ and with the control $1 \cdot 0$. The difference, 1.3 , had a standard error of 0.16 and was significant at the $1 \%$ level by Student's $t$ test. Three of the observers had difficulty in reading the tests. $\vec{\theta}$ The remaining eight all recorded adequate differences $\infty$ for the gonococcal strains though their absolute levels for test and control varied. Observer error was not analysed further since it was clear that the major problem was high scoring with the control reagent. When this was replaced by one in which the staphylococci were coated with normal immunoglobulin the controls became negative and observer variation insignificant.

EFFECT OF SERUM IN CULTURE MEDIA To assess the effect on the coagglutination test of the presence of serum in the culture plates from which the organisms were taken 100 strains of $N$. gonorrhoeae freshly isolated from male and female clinical cases were cultured for 24-48 hours on both serumcontaining media (Oxoid and Difco Gc selective 을 media) and serum-free media (Difco unselective serum-free medium). Six strains of $N$. meningitidis were similarly cultured. One was from the throat of a healthy volunteer and five were donated by the $\sigma$ Standards Laboratory for Serological Reagents, N Colindale. Twenty strains of other Neisseria species $N$ freshly isolated from the throats of healthy volunteers were also cultured. The results from the two types of medium were very similar for all the Neisseria strains tested (Table 2).

DETECTION OF N. GONORRHOEAE

A further 140 strains of $N$. gonorrhoeae freshly isolated from urogenital, rectal, and throat swabs 
were tested for coagglutination and the results were compared with the usual laboratory tests for gonococcal identification, including oxidase reaction, Gram staining, and immunofluorescent microscopy. Sugar fermentation reactions on serum-free slopes (Difco reagents) were also performed on some strains. Of the 140 strains of $N$. gonorrhoeae tested with the improved control reagent 137 gave a positive coagglutination reaction, two gave negative reactions, and one was autoagglutinating - a positivity rate of $98 \%$ (Table 3). A number of strains died out before extensive testing could be completed, but in eight strains in which the original immunofluorescent staining was negative repeat testing showed a positive reaction and sugar fermentations typical of $N$. gonorrhoeae. In a further five strains showing similar preliminary results repeated immunofluorescent staining was positive. The mean rating for the strains of $N$. gonorrhoeae in the test was ++ with reactions which were quite clear to read.

OTHER SPECIES OF NEISSERIA

Forty-six strains of Neisseria other than $N$. gonorrhoeae isolated from clinical specimens and from healthy volunteers were also tested. They included 10 strains of $N$. meningitidis. Twenty-nine organisms of other genera that had grown on the selective gonococcal culture media were identified by standard methods (Cowan 1974) and tested for coagglutination.

Table 4 shows the coagglutination results for Neisseria species other than N. gonorrhoeae. Out of 10 strains of $N$. meningitidis tested six gave positive reactions, two negative reactions, and two were autoagglutinating. Excluding the latter, this was a $75 \%$ positivity rate. Out of 25 Neisseria species other than $N$. gonorrhoeae and $N$. meningitidis tested six were positive, nine negative, and 10 autoagglutinating. Excluding the latter this was a positivity rate of $40 \%$. In addition there were three negative and two autoagglutinating strains isolated from throat swabs which were not tested for sugar fermentation, and one negative and five positive strains isolated from genital and rectal sources which were also not tested for fermentation. The identity of these Neisseria strains cannot be further established but possibly some might be $N$. gonorrhoeae with falsely negative immunofluorescence, as was found in some strains shown in Table 5.

\section{OTHER ORGANISMS}

The coagglutination results for some organisms other than Neisseria cultured from clinical sources

Table 2 Effect on coagglutination of serum in culture medium

\begin{tabular}{|c|c|c|c|c|c|c|}
\hline \multirow{2}{*}{$\begin{array}{l}\text { Coagglutination } \\
\text { rating }\end{array}$} & \multicolumn{2}{|c|}{ N. gonorrhoeae } & \multicolumn{2}{|c|}{ N. meningitidis } & \multicolumn{2}{|c|}{ Other Neisseria $s p p$} \\
\hline & $S^{\boldsymbol{a}}$ & $N^{c}$ & $S^{b}$ & $N^{e}$ & $S^{b}$ & $N^{c}$ \\
\hline $\begin{array}{l}+++ \\
\dot{+}+ \\
\bar{\vdots} \\
\overline{-} \\
\text { Autoagglutinating } \\
\text { No. strains tested }\end{array}$ & $\begin{array}{r}34^{*} \\
44 \\
20 \\
2 \\
0 \\
0\end{array}$ & $\begin{array}{r}34 \\
44 \\
16 \\
6 \\
0 \\
0\end{array}$ & $\begin{array}{l}1 \\
3 \\
0 \\
0 \\
0 \\
2\end{array}$ & $\begin{array}{l}2 \\
2 \\
0 \\
0 \\
0 \\
2\end{array}$ & $\begin{array}{l}0 \\
3 \\
2 \\
0 \\
6 \\
9\end{array}$ & $\begin{array}{l}1 \\
2 \\
2 \\
0 \\
6 \\
9\end{array}$ \\
\hline
\end{tabular}

$a=$ Oxoid Gc selective medium. $b=$ Difco Gc selective medium. $c=$ Difco serum-free medium. $\mathbf{S}=$ serum containing. $\mathbf{N}=$ no serum.

* No. of strains.

Table 3 Coagglutination results for strains of $\mathrm{N}$. gonorrhoeae

\begin{tabular}{|c|c|c|c|c|c|c|c|c|c|c|c|c|c|c|c|}
\hline & \multirow[t]{2}{*}{ No.strains } & \multicolumn{3}{|c|}{ Origin of isolates } & \multirow[t]{2}{*}{ Oxidase } & \multirow[t]{2}{*}{ Gram } & \multirow[t]{2}{*}{$I F_{1}$} & \multirow[t]{2}{*}{$I F_{2}$} & \multirow{2}{*}{$\begin{array}{l}\text { Sugar } \\
\text { fermentations }\end{array}$} & \multicolumn{6}{|c|}{ No. strains at coagglutination rating } \\
\hline & & Urogenital & Rectal & Throat & & & & & & $3+$ & $2+$ & $1+$ & $\begin{array}{l}\text { Total } \\
\text { positive }\end{array}$ & Negative & $A A$ \\
\hline & 103 & 88 & 14 & 1 & + & - & + & ND & ND & 27 & 53 & 22 & 102 & 1 & $\mathbf{0}$ \\
\hline & 24 & 20 & 4 & 0 & + & - & + & + & Dextrose only & 7 & 10 & 5 & 22 & 1 & 1 \\
\hline & 8 & 6 & 2 & 0 & + & - & - & + & Dextrose only & 2 & 3 & 3 & 8 & 0 & $\mathbf{0}$ \\
\hline & 5 & 3 & 1 & 1 & + & - & - & + & ND & 1 & 3 & 1 & 5 & 0 & $\mathbf{0}$ \\
\hline Total & 140 & 117 & 21 & 2 & & & & & & 37 & 69 & 31 & 137 & 2 & 1 \\
\hline
\end{tabular}

$I F_{1}=$ routine diagnostic immunofluorescent antibody test on fresh isolate.

$I F_{2}=$ subsequent repeat immunofluorescent antibody test.

ND $=$ not done.

$\mathbf{A A}=$ autoagglutination. 
Table 4 Coagglutination results for Neisseria spp other than N. gonorrhoeae

\begin{tabular}{|c|c|c|c|c|c|c|c|c|c|c|c|c|c|c|c|c|}
\hline \multirow[t]{2}{*}{ Organism } & \multirow{2}{*}{$\begin{array}{l}\text { No. of } \\
\text { strains }\end{array}$} & \multicolumn{4}{|c|}{ Origin of isolates } & \multirow[t]{2}{*}{ Oxidase } & \multirow[t]{2}{*}{ Gram } & \multirow[t]{2}{*}{$\boldsymbol{I F}$} & \multirow{2}{*}{$\begin{array}{l}\text { Sugar } \\
\text { fermentations }\end{array}$} & \multicolumn{6}{|c|}{ No. strains at coagglutination rating } & $\begin{array}{l}\text { Mear突 } \\
\text { scores }\end{array}$ \\
\hline & & Genital & Rectal & Throat & $\begin{array}{l}\text { Ref } \\
l a b\end{array}$ & & & & & $3+$ & $2+$ & $1+$ & $\begin{array}{l}\text { Total } \\
+\end{array}$ & - & $A A$ & \\
\hline $\begin{array}{l}\text { N.meningitidis } \\
\text { Neisseria spp }\end{array}$ & $\begin{array}{r}10 \\
25 \\
5\end{array}$ & $\begin{array}{l}1 \\
0 \\
0\end{array}$ & $\begin{array}{l}0 \\
2 \\
0\end{array}$ & $\begin{array}{r}4 \\
23\end{array}$ & $\begin{array}{l}5 \\
0\end{array}$ & $\begin{array}{l}+ \\
+ \\
+\end{array}$ & $\begin{array}{l}- \\
- \\
-\end{array}$ & $\begin{array}{l}- \\
- \\
-\end{array}$ & $\begin{array}{l}\mathrm{D}+\mathrm{M} \\
\text { Other than } \mathrm{D} \\
\mathrm{D}+\mathrm{M} \\
\mathrm{ND}\end{array}$ & $\begin{array}{l}2 \\
0 \\
0\end{array}$ & $\begin{array}{l}3 \\
3 \\
0\end{array}$ & $\begin{array}{l}1 \\
3\end{array}$ & $\begin{array}{l}6 \\
6 \\
0\end{array}$ & $\begin{array}{l}2 \\
9 \\
3\end{array}$ & $\begin{array}{r}2 \\
10 \\
2\end{array}$ & $\begin{array}{l}1.6 \\
0.6\end{array}$ \\
\hline $\begin{array}{l}\text { Identification } \\
\text { incomplete }\end{array}$ & 6 & 4 & 2 & 0 & 0 & + & - & - & ND & 1 & 2 & 2 & 5 & 1 & 0 & 1.5 \\
\hline \multicolumn{17}{|c|}{$\begin{array}{l}\text { IF = gonococcal immunofluorescent antibody test. } \\
\text { Ref lab = strains from the Standards Laboratory for Serological Reagents, Cent } \\
N . \text { menigitidis group A (2), group B (2), group C (1). } \\
\text { D = dextrose. } \mathrm{M}=\text { maltose. } \\
\text { AA = autoagglutination. } \\
\text { ND = not done. } \\
\text { Table } 5 \text { Coagglutination results for organisms other than neisseria }\end{array}$} \\
\hline \multirow[t]{2}{*}{ Organism } & & & \multirow[t]{2}{*}{ No. of stra } & \multicolumn{5}{|c|}{ Origin of isolates } & $I F$ & & \multicolumn{5}{|c|}{ No. strains at coagglutination rating } & \\
\hline & & & & \multicolumn{2}{|c|}{ Genital } & Rectal & \multicolumn{2}{|c|}{ Throat } & & & \multicolumn{2}{|c|}{ Positive } & \multicolumn{2}{|l|}{ Negative } & $A A$ & \\
\hline \multicolumn{3}{|c|}{$\begin{array}{l}\text { Streptococcus viridans } \\
\text { Streptococcus faecalis } \\
\text { Escherichia coli } \\
\text { Staphylococcus epidermidis } \\
\text { Candida spp }\end{array}$} & $\begin{array}{r}2 \\
11 \\
1 \\
1 \\
14\end{array}$ & \multicolumn{2}{|l|}{$\begin{array}{r}0 \\
6 \\
0 \\
1 \\
14\end{array}$} & $\begin{array}{l}1 \\
4 \\
1 \\
0 \\
0\end{array}$ & $\begin{array}{l}1 \\
1 \\
0 \\
0 \\
0\end{array}$ & & $\begin{array}{l}- \\
- \\
-\end{array}$ & & $\begin{array}{l}0 \\
0 \\
0 \\
0 \\
0\end{array}$ & & $\begin{array}{r}1 \\
9 \\
1 \\
1 \\
14\end{array}$ & & $\begin{array}{l}1 \\
2 \\
0 \\
0 \\
0\end{array}$ & \\
\hline
\end{tabular}

on the selective diagnostic plates are shown in Table 5 . No strain gave a positive coagglutination reaction though some streptococcal strains were autoagglutinating. Candida spp gave finely granular reactions in both test and control pools. A smear of cervical epithelial debris was taken from the surface of a culture plate and also gave a negative reaction with the test.

\section{Discussion}

In the demonstration experiment the observers had had no previous experience with the test and observer options on a rating system such as this are partly subjective. Experience with the test is important, particularly in distinguishing between coagglutination and granular or autoagglutinating reactions.

The results of the preliminary tests were poor, the problem being the relation of a fairly low reagent score to a high control score. This experiment and others in the early phase of our investigation of the coagglutination test showed confusing reactions in the control, which at that stage was made up with protein A-bearing staphylococci uncoated with antibody. Subsequently a control reagent was prepared in which the staphylococci were coated with normal rabbit immunoglobulin and this gave much clearer results. For positive tests to be readable there must be an easily distinguishable difference between thes test and control reactions.

The results of tests from serum-containing median

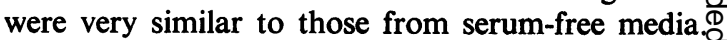
We expected that the presence of serum from the $\Rightarrow$ medium might interfere with the test but this was not so with the media we employed. Many laboratories? in Great Britain use serum-containing media for the isolation of $N$. gonorrhoeae and it would have been a serious limitation on the usefulness of the test if sucho cultures were unsuitable for it.

Ninety-eight per cent of the 140 strains identified as $N$. gonorrhoeae by conventional laboratory testsᄋ gave positive reactions with the improved reagents. Although this correlation between the tests was very? good the discrimination between $N$. gonorrhoeae and other Neisseria species was poor. Seventy-five per cent of testable (non-agglutinating) meningococcin and $40 \%$ of testable strains of other species gave positive results. However, no organisms other than Neisseria gave a positive result.

Our findings contrast with those of Menck (1976), who found the test useful for distinguishing betweeno different Neisseria species in pharyngeal specimens. He overcame the problem of what he called 'pseudo-? coagglutination' in some strains by adding a drop of trypsin solution to the smear on the slide. This technique should be investigated further.

We consider that the test might be useful for the 
detection of Neisseria cultured from urogenital and rectal specimens, which are unlikely to be $N$. meningitidis, but that at present it would be unsuitable for the identification of gonococci from the pharynx, where other Neisseria are usually encountered. The major problem is to improve the specificity of the antibody used to coat the staphylococci. If this can be done the tests should prove a useful and acceptable addition to current diagnostic techniques.

We are grateful to Pharmacia Diagnostics AB, Uppsala, Sweden, for supplies of the prototype gonococcus coagglutination test material and to the Standards Laboratory, Central Public Health Laboratory, Colindale Avenue, London, for the donation of five strains of $N$. meningitidis.

\section{References}

Arvilommi, H. (1976). Grouping of beta-haemolytic streptococci by using coagglutination, precipitation or bacitracin sensitivity. Acta Pathologica et Microbiologica Scandinavica, 84B, 79-84.

Christensen, P., Kahlmeter, G., Jonsson, S., and Kronvall, G. (1973). New method for the serological grouping of streptococci with specific antibodies adsorbed to protein A-containing staphylococci. Infection and Immunity, 7, 881-885.

Cowan, S. T. (1974). Cowan and Steel's Manual for the
Identification of Medical Bacteria, 2nd ed. Cambridge University Press.

Danielsson, D., and Kronvall, G. (1974). Slide agglutination method for the serological identification of Neisseria gonorrhoeae with antigonococcal antibodies adsorbed to protein A-containing staphylococci. Applied Microbiology, 27, 368-374.

Edwards, E. A., and Larson, G. L. (1974). New method of grouping beta-haemolytic streptococci directly on sheep blood agar plates by coagglutination of specifically sensitised protein A-containing staphylococci. Applied Microbiology, 28, 972-976.

Hahn, G., and Nyberg, I. (1976). Identification of streptococcal groups A, B, C, and $\mathrm{G}$ by slide coagglutination of antibody-sensitized protein A-containing staphylococci. Journal of Clinical Microbiology, 4, 99101.

Juhlin, I., and Winblad, S. (1973). Sero-typing of mycobacteria by a new technique using antibody globulin adsorbed to staphylococcal protein A. Acta Pathologica et Microbiologica Scandinavica, 81B, 179-180.

Kronvall, G. (1973). A rapid slide-agglutination method for typing pneumococci by means of specific antibody adsorbed to protein A-containing staphylococci. Journal of Medical Microbiology, 6, 187-190.

Maxted, W. R., Efstratiou, A., and Parker, M. T. (1976). Agglutination grouping of streptococci (Letter). Lancet, 2, 692-693.

Menck, H. (1976). Identification of Neisseria gonorrhoeae in cultures from tonsillo-pharyngeal specimens by means of a slide coagglutination test (Phadebact Gonococcus Test). Acta Pathologica et Microbiologica Scandinavica, 84B, 139-144. 